\title{
The Gospel of Anti-Americanism in South Korea: Mass Media Exposure and Negative Audience Perception
}

\author{
Running Head: Media Exposure, Perceptions \&Evaluation
}

\author{
Seung-jun Moon \\ Department of Communication and Information, Inha University, South Korea
}

Copyright $\bigcirc 2016$ by authors, all rights reserved. Authors agree that this article remains permanently open access under the terms of the Creative Commons Attribution License 4.0 International License

\begin{abstract}
Although there are many reasons behind anti-Americanism in South Korea in the $21^{\text {st }}$ century, it is believed by some experts that the anti-Americanism originated over a decade ago from the 2002 Olympic short track speed skating controversy, and the issues with the Boeing F-15K. Based on exemplification and social cognitive theories, this study examines the extent to which exposure to the South Korean mass media coverage of these two concrete exemplars of negative American images, Olympic short track speed skating and the Boeing F-15K, affected South Koreans' negative perceptions of America. Results revealed that the South Korean mass media coverage of negative American images serves as the basis for evaluating two well-known American-coded issues: the American soccer team's performance in the 2002 South Korea and Japan World Cup, and the terrorist attack on the World Trade Center in 2001.
\end{abstract}

Keywords Media Exposure, Perceptions, Evaluation

\section{Introduction}

Since our external reality is socially constructed, it is impossible for us to explore every social phenomenon first-hand [23]. Therefore, there is no alternative but to rely on indirect information sources, such as the mass media, in attempting to reach beyond our limited domains [6]. Thus, the audience is dependent on the mass media disseminating accurate information so that they can make informed judgments. Frequently, information disseminated by the media may be biased and subjective, particularly when reporting on international issues, tending to reflect the foreign policy interests of the nation in which the messages are produced [11].

In reporting on international issues, media tends to adopt a "pro-government" stance, which causes the viewpoint of each country's media on the same issues to vary. Although it is debatable whether media in democratic countries should support the home government, a number of scholars have indeed found evidence of media supporting the home government [4].

This biased coverage sometimes infuses the audience's negative perceptions of the other group. Once categorized as a member of a certain rival group, an individual in the group is expected to possess the same characteristics as that group and is evaluated on the basis of that category [9]. Even though such perceptions are not necessarily negative, they can be destructive when the media in the dominant group portray the other group with a negative bias. Also, these negative perceptions may provide members of the dominant group with the basis for judging or evaluating the issues related to the other group [10].

In the $21^{\text {st }}$ century, anti-Americanism formed in many places: Germany [13], Lebanon [20], Greece [22], Turkey [28], and other countries in Europe [24]. At the same time, anti-Americanism formed in South Korea despite the fact that America and South Korea have been allies since the South Korean War. Interestingly, according to the South Korea Tourist Service, less than five percent of South Koreans have been to America. ${ }^{1}$ Even though most South Koreans in South Korea have not had direct contact with Americans, anti-Americanism has become widespread among South Korean citizens in the 2000s. In particular, some restaurants and stores in South Korea refuse to serve American customers, and boycotts of American products have taken place on a national scale (see Figure 1). 


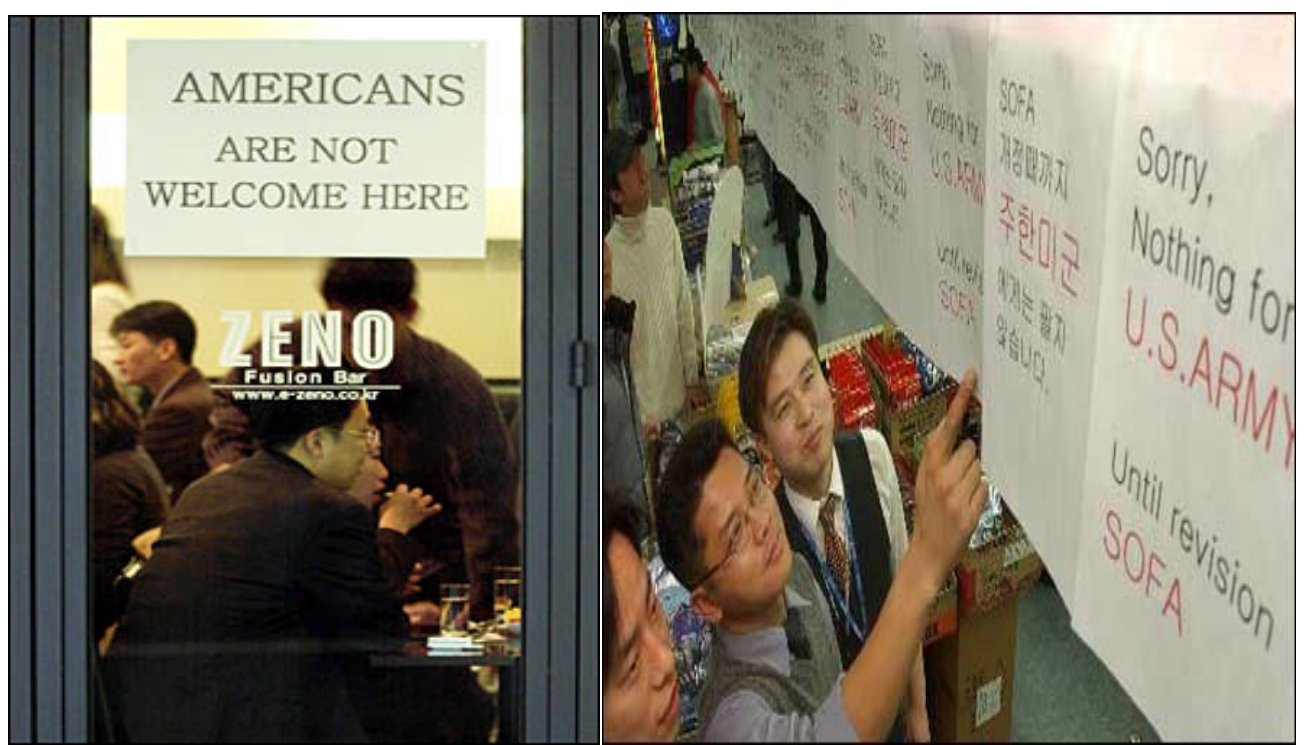

Figure 1. A restaurant and shopping mall in Seoul, South Korea in 2002 (South Korea Chosun Journal, March, 2002).

This trend raises the question of what factors have contributed to this anti-American sentiment, especially when most South Koreans do not have first-hand contact with Americans. It can be surmised that the negative images of Americans found in the South Korean mass media is one contributing factor. In particular, several pro-American groups have suggested that the negatively biased the South Korean mass media coverage of Americans, along with negatively mistranslated messages of the American mass media from English into South Korean, have facilitated South Korean anti-Americanism [14]. These groups have criticized the South Korean mass media's biased coverage of Americans, and insist that the South Korean mass media's production of negative images should be limited so that relations between the two countries do not grow worse.

The purpose of this research is to study how exposure to negative images of Americans in the South Korean mass media influences South Koreans' perception formation of Americans when they lack real-world experience of Americans. To analyze this influence, two representative issues, which the South Korean mass media covered with negative images of Americans, were examined: Apolo Ohno vs. Dong-sung Kim in the men's 1,500-meter short track speed skating finals in the 2002 Salt Lake City Winter Olympic Games, and the American company Boeing's buyout policy in the 2002 South Korean Fighter Procurement Project. Although these issues took place almost 10 years ago, they still get much attention whenever anti-Americanism is mentioned. Some South Korean experts have stated that current anti-Americanism originated over a decade ago from the 2002 Salt Lake City Winter Olympic Games, and the American company Boeing's buyout policy in the 2002 South Korean Fighter Procurement Project, because these two issues were extremely emotional conflicts between nations, not just individuals or groups.

Anti-Americanism surged strongly in South Korea in
2002. As Seen in Figure 1, Americans could not get into some South Korean restaurants. Simultaneously, the issues of Boeing's buyout policy in the 2002 Korean restaurants. Simultaneously, the issues of Boeing's buyout policy in the 2002 Korean Fighter Procurement Project, and the controversy of Apolo Phno vs. Dong-sung Kim in the 2002 Salt Lake City Winter Olympic Games caused South Koreans to get negative images toward America. These negative images were reported in the South Korean mass media. Finally, Korean soccer players' goal ceremony imitating Ohno's short track motions exactly illustrated the images that South Koreans had toward America, as shown in Figure 2.

In addition, this research will also test the relationship between South Koreans' perceptions formed from the South Korean mass media coverage of these negative exemplars and South Koreans' evaluation of two American-coded issues: the performance of the U.S. World Cup Soccer Team in the 2002 South Korea-Japan World Cup after the development of nationwide anti-Americanism, and the terrorist attacks on the World Trade Center in 2001, before nationwide anti-Americanism.

\section{Background: Two Historical Anti-Americanism Issues in South Korea}

Thousands of South Koreans took to the streets yesterday in Seoul, urging citizens to boycott U.S. goods and instead buy domestic products. They encouraged South Koreans to show love for their country by refusing to buy U.S. products [26]. Anti-American sentiment has been running high among some sectors of the public since the controversial ruling at the 2002 Salt Lake City Winter Olympic Games that stripped South Korean short track speed skater Kim Dong-Sung of the 1,500-meter gold medal. Before this boycott ended, the apparent selection of the American Boeing F-15K as the South Korean Air Force's new fighter plane further aroused anti-American sentiment [27]. 
Historical issue reflecting Anti-Americanism 1: Negative perceptions of Americans formed by the issue of Ohno vs. Kim in Salt Lake City, Utah, USA. Negatively remembered by most South Koreans, Apolo Ohno is still on the minds of many South Koreans; enough to create interest in his official retirement announcement [2]. More than 10 years ago, in February 2002, the men's 1,500-meter short track speedskating finals of the Salt Lake City Winter Olympic Games took place with an American skater, Apolo Ohno, and a South Korean skater, Dong-sung Kim. In this final, Kim of South Korea crossed the finish line first, but moments later he was disqualified by the chief referee on the grounds that he blocked Ohno during the race. Ohno was given the gold medal, and South Koreans all over South Korea were outraged. The South Korean mass media suggested that Ohno overacted, pretending to be blocked by $\mathrm{Kim}$, and raising his right-hand during the race to imply this to the referees. Jay Leno, an American talk show host, exacerbated the situation by saying that "the angry South Korean athlete, namely Dong-sung Kim, might have gone home, kicked his dog and eaten it."

One nationwide poll in South Korea on the general images of the 2002 Winter Olympic Games revealed that 11,167 $(70.83 \%)$ of 15,765 respondents gave the coverage a rating between 0 and $20 \%, 2,553(16.19 \%)$ respondents rated it between 20 and $40 \%, 1,443(9.15 \%)$ respondents rated it between 40 and $60 \%, 289(1.83 \%)$ respondents rated it between 60 and $80 \%$, and only $313(1.99 \%)$ rated it between 80 and $100 \%$ on a 100 point scale. ${ }^{2}$ Most respondents who participated in the nationwide poll thought the Olympic Games were biased toward Americans. According to another nationwide poll, due to Kim's disqualification and the American talk show host's racial discrimination, 4,532 $(89 \%)$ of 5,095 respondents agreed with the boycott of American products, while only $489(10 \%)$ respondents disagreed. $^{3}$

Historical issue reflecting Anti-Americanism2: Negative perceptions of Americans formed by the issue of the F-15K vs. the Rafale in Seoul, South Korea. Since the early 2000s, South Korea has faced the need to produce a new generation of military aircraft. The project to develop a new fleet, the South Korean Fighter Procurement Project, includes plans to operate the new fighters until 2040. Candidates for this project included America's BoeingF-15K, France's Rafale, Russia's Sukhoi Su-35., and the Eurofighter Typhoon offered by a consortium from Britain, Italy, and the Netherlands.

In the first phase of evaluation, the French-built Rafale and the European consortium Eurofighter led the four-way competition. Both were very close in terms of costs, technology transfer, and compatibility with existing weapons systems. South Korean military pilots officially supported the Rafale due to its excellent operational capabilities and flying speed. This project attracted public attention due to its large expense - more than $\$ 4.6$ billion of the national budget. Before the South Korean government decided which aircraft to use, one nationwide poll asked 4,191 respondents about their preference among the four fighters. Of the respondents, 2,893 (69\%) chose France's Rafale, 529 (13\%) of respondents chose the Eurofighter, and 498 of respondents (12\%) chose the Russian Sukhoi as the best fighter for the South Korean Air-Force. Only 271 (6\%) of the respondents chose the American Boeing F-15K. ${ }^{4}$

Despite the polling results, in the second phase of evaluation South Korea chose the American company Boeing to be the supplier for 40 new fighter jets. Later, it was revealed by several South Korean journalists that the F-15K was chosen due to Boeing's illegal lobby of South Korean government officers, as well as the result of U.S. governmental pressure [27]. At the time, public opinion in the media was strongly opposed to the government's selection of the Boeing F-15K as the winner of the South Korean Fighter Procurement Project [12].

Evaluation of the American soccer team's performance in the 2002 South Korea-Japan World Cup. After the Salt Lake City Olympic Games and the Boeing F-15K controversies, anti-Americanism rose significantly in all regions of South Korea. It was under these circumstances that South Korea and Japan co-held the 2002 South Korea-Japan World Cup in May. In this World Cup, South Korea and the U.S. were in Group D, along with Portugal and Poland. Among the teams in Group D, only two of each group were to proceed to the second round. According to polls, respondents were to predict which team a South Korean team would need to beat to join the second-round in group D. Among the respondents, 418 (35\%) chose the U.S., 287 (24\%) respondents chose Poland, and 53 (4\%) respondents chose Portugal, while 438 (37\%) respondents did not choose any country. ${ }^{5}$ The result of several nationwide polls clearly illustrates the degree of South Koreans' negative perceptions toward the American soccer team's performance.

Due to the severe anti-Americanism at that time, 10,000 South Korean police were dispatched to the stadium to protect the U.S. soccer team, and U.S. intelligence officers were also involved in protecting the U.S. team and staff during the match between America and South Korea [18]. Simultaneously, 6,000 police were dispatched to protect the U.S. Embassy located in Seoul. For security reasons, the U.S. Embassy temporarily suspended its public affairs until the match was over [21]. The June 2002 World Cup soccer match between South Korea and America ended in a tie. After the South Korean team scored the tying goal, South Korean players performed a goal ceremony imitating Ohno's controversial motions in the 2002 Winter Olympic short track speed skating competition that disqualified South Korean skater Kim Dong-Sung. (See Figure 2). 


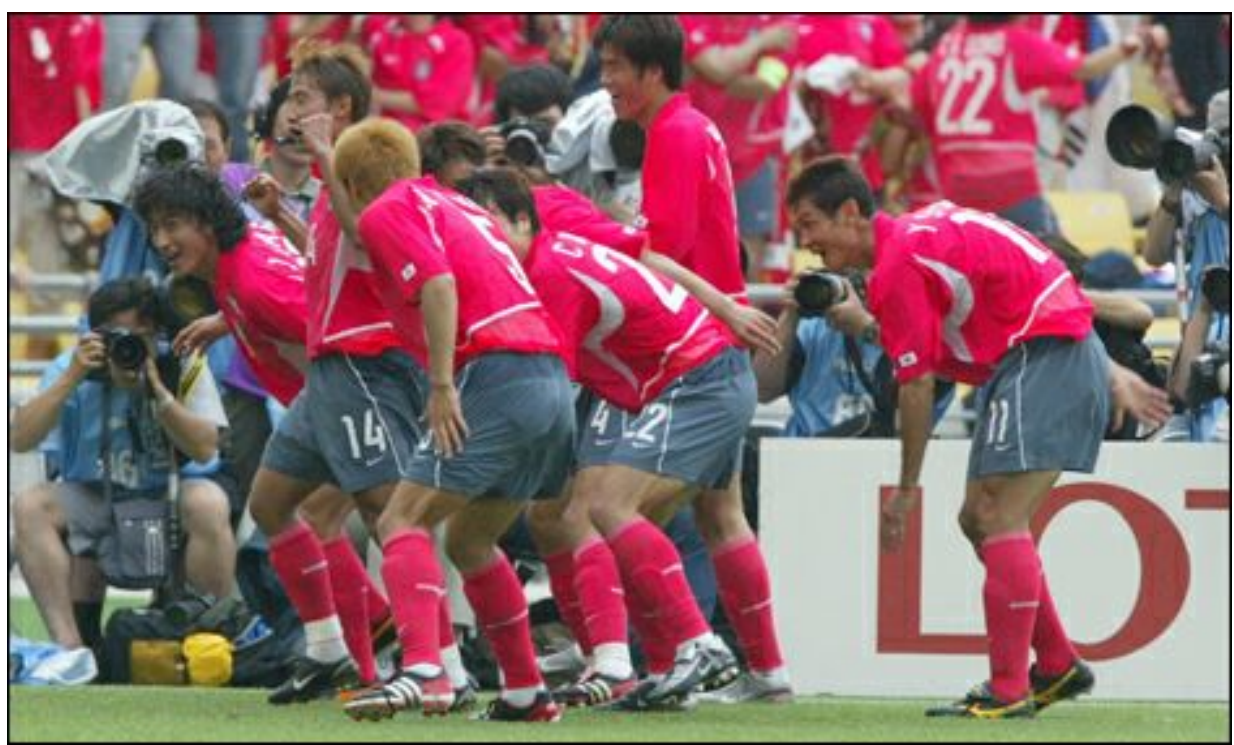

Figure 2. South Korean players' goal ceremony imitating Ohno's short track motions (South Korea Sports Seoul, June, 2002).

Evaluation of the terrorist attack on the World Trade Center in 2001. Before severe anti-Americanism rose in South Korea around the 2000s, the image of Americans was at least neutral, and America was one of South Korea's favored nations. For example, when terrorists attacked New York City and Washington D.C. on September $11^{\text {th }}, 2001$, South Korean citizens expressed shock and regret [16], 2001). South Korean national television stations stopped regular programming and broadcast vivid live scenes from New York City and Washington, D.C. [19].

Against this backdrop, the President of South Korea officially expressed his full support of the U.S. initiatives in dealing with the September $11^{\text {th }}$ catastrophe. In a message addressed to his U.S. counterpart, the President of South Korea pledged support to President George Bush's efforts to terminate terrorism [7]. The South Korean government's contributions to the U.S. included medical and logistical support, but not the dispatch of combat troops [25]. Around this time, one nationwide survey revealed that among 1,895 participants, an overwhelming $92 \%$ of South Korean respondents agreed with the decision to help the US, while only $147(8 \%)$ respondents did not agree. According to another poll of 14,678 respondents, 10,821 (73.72\%) respondents agreed with America's decision to settle the conflict by force against terrorism, while 3,857 (26.28\%) respondents did not agree. ${ }^{6}$ It can be inferred that if a similar poll had been conducted around the time that anti-Americanism prevailed in South Korea, it would have produced very different results.

\section{Theoretical Framework}

Exemplification theory: learning perceptions from exemplars of covering images. Zillman's [29] exemplification theory is a psychological approach for testing how social issues that are covered in the mass media influence audience perception formation. Audiences tend to have some tacit understanding of the relation between an example (called an exemplar) covered in the mass media and the large entity exemplified by it. In particular, messages containing emotionally-charged exemplars have a substantially greater impact on the audience's perception formation than base-rate information, which consists of summary data such as statistical or scientific principles. Also, this formed perception fosters audiences' evaluation of similar occurrences in later encounters, and serves as the basis for evaluating a larger body related to the issue.

Exemplification theory can be applied to South Koreans' perception formation toward Americans and their evaluation of American-coded issues. The South Korean mass media is the best source of information on American events for South Koreans who do not have regular direct contact with Americans. As South Korea is a fairly homogeneous society, it is assumed that most South Koreans tend to evaluate Americans based on perceptions acquired from the South Korean mass media, whether the mass media cover Americans accurately or not. Based on this assumption, it is expected that a series of negatively covered exemplars of Americans, the Ohno controversy and the F-15K scandal, arouse negative perceptions among South Koreans in South Korea. Such negative perceptions probably led South Koreans toward a negative evaluation of the American soccer team's performance at the 2002 South Korea-Japan World Cup, and toward a positive evaluation of previous events, such as the terrorist attacks on the World Trade Center in 2001.

Social cognitive theory: perception formation from vicarious observation through media. One of the main arguments of exemplification theory is that, regardless of its accuracy, a series of exemplar information with emotionally covered exemplars has a substantial impact on the perception formation of the audience. Bandura's [3] social cognitive theory shares certain assumptions with exemplification theory. According to Bandura, people come to understand certain social phenomena in many ways. Vicarious 
observation of media is one way to learn social perceptions, attitudes, and values. In order to explain people's knowledge formation from vicarious observation, Bandura [3] has suggested that human learning is the result of the following four major subfunctions of media: attention (observation), retention (storing of constructs), production (acting out), and motivation (reward and/or punishment) from media exposure. Through these subfunctions, people tend to imitate what they are exposed to in media content, and they form similar perceptions toward the image. In particular, Bandura [3] demonstrated that people could imitate and learn by observation. He showed films of unusual forms of physical and verbal aggression to groups of children. Subjects in the experimental group saw a movie in which a woman was severely attacking an inflated bobo doll. After seeing this scene, the children became mildly excited and tried to imitate the observed scene.

Bandura's four major subfunctions and his experiment explain the process of how South Koreans form perceptions of Americans, and why South Korean World Cup soccer players imitated Ohno's actions. Similar to the children's reaction in Bandura's bobo doll experiment, South Koreans exposed to both the Ohno and F-15K issues likely developed negative perceptions of Americans, which in turn led South Korean soccer players to scornfully imitate Ohno's actions in their soccer match with America (see Figure 2). Thus, it can be inferred that when South Koreans remember something related to Americans from the South Korean mass media covered images of Americans, they tend to form perceptions which influence how they react to subsequent American-coded issues. Whether this reaction is positive or negative will depend on the perception formed from observation of the mass media.

\section{Hypotheses}

This study tests the key point that surmises that South Koreans who have little or no contact with Americans will form perceptions of Americans influenced by the South Korean mass media exposure coverage of American issues. Further, international conflicts, especially the Olympic speed skating controversy and the U.S. Boeing F-15K issue, might affect the origin of the anti-Americanism of South Koreans, and it is expected that such formed perceptions affect South Koreans' evaluation of American-coded issues. Thus, it is predicted that the South Korean mass media coverage of American issues indirectly influences South Koreans' evaluation of American-coded issues through formation of perceptions based on biased coverage of exemplars by the mass media.

Both exemplification theory and social cognitive theory provide theoretical rationales for our expectation that exemplar coverage of negative American images via the South Korean mass media will be positively related to South Koreans' negative perceptions of Americans (see H1 \& H2). Also, it is surmised that perception and evaluation are theoretically correlated because people tend to evaluate future events, based on their perceptions. Thus, South
Korean perceptions of Americans are theoretically related to the evaluation of American-coded issues. For example, if a South Korean has positive perceptions of Americans, he/she will have a positive evaluation of the American soccer team's performance in the 2002 South Korea-Japan World Cup (see H3 \& H4). Also, if a South Korean has positive perceptions of Americans, he/she will have a negative evaluation of the terrorist attack on the World Trade Center in 2001 (see H5 \& H6).

It is expected that people tend to acquire negative or positive perceptions of an event after media exposure, and these perceptions in turn probably affect people's positive or negative evaluation, depending on the media bias, toward future events. Thus, it is predicted that the South Korean mass media coverage of negative American images is positively related (through perceptions of Americans) to South Koreans' negative evaluation of the American soccer team's performance in the 2002 South Korea and Japan World Cup (see H7 \& H9), and positive evaluation of the terrorist attack on the World Trade Center in 2001 (see H8 \& H10). Based on these assumptions, the following hypotheses are proposed.

H1: Exposure to the South Korean mass media coverage of the Ohno issue is related to South Koreans' negative perceptions of the American Olympic Team's performance in Salt Lake City.

H2: Exposure to the South Korean mass media coverage of the Boeing F-15K issue is related to South Koreans' negative perceptions of the American government.

H3: South Koreans' positive perception of the American Olympic Team's performance in Salt Lake City is related to the positive evaluation of the American soccer team's performance in the 2002 South Korea-Japan World Cup.

H4: South Koreans' positive perception of the American government is related to the positive evaluation of the American soccer team's performance in the 2002 South Korea-Japan World Cup.

H5: South Koreans' positive perception of the American Olympic Team's performance in Salt Lake City is related to the negative evaluation of the terrorist attack on the World Trade Center in 2001.

H6: South Koreans' positive perception of American government is related to the negative evaluation of the terrorist attack on the World Trade Center in 2001.

H7: Exposure to the South Korean mass media coverage of the Ohno issue is indirectly related through perceptions of the American Olympic Team's performance in Salt Lake City to South Koreans' negative evaluation of the American soccer team's performance in the World Cup.

H8: Exposure to the South Korean mass media coverage of the Ohno issue is indirectly related through perceptions of the American Olympic Team's performance in Salt Lake City to South Koreans' positive evaluation of the terrorist attack on the World Trade Center. 
H9: Exposure to the South Korean mass media coverage of the Boeing $\mathrm{F}-15 \mathrm{~K}$ issue is indirectly related through perceptions of the American government to South Koreans' negative evaluation of the American soccer team's performance in the 2002 South Korea-Japan World Cup.

H10: Exposure to the South Korean mass media coverage of the Boeing $\mathrm{F}-15 \mathrm{~K}$ issue is indirectly related through perceptions of the American government to South Koreans' positive evaluation of the terrorist attack on the World Trade Center.

\section{Method}

Sample. The original questionnaire was in English, and translated into South Korean by a native South Korean speaker. Then, the South Korean version was translated back into English. Finally, the original English version and the retranslated English version were compared by bilingual researchers. We concluded that the two English questionnaires were almost the same in terms of their content and that the original intention of the American researcher was accurately conveyed in the South Korean versions, meaning that validity of the translations was excellent.

Two South Korean churches located in the inner city of Seoul, South Korea were chosen as the survey sites. Even though the churches have a weakness in that subjects draw congregates from the same religion, they offer the advantage of attracting South Koreans from different socioeconomic levels. A self-administered questionnaire written in South Korean was distributed to 300 South Korean volunteers at the two South Korean churches using purposive sampling method. After collecting the data, South Koreans who (1) were born in South Korea, (2) were currently older than eighteen years old, (3) clearly remember the two anti-Americanism issues focused on in this study, (4) had never been to America, and (5) did not have family members or friends directly or indirectly involved in the Ohno issue, the F-15K issue, the 2002 World Cup, or September 11th, were selected as our main subjects. It was assumed that this subgroup probably did not have an opportunity for regular direct contact with American culture except through the South Korean mass media.

\section{Results}

After coding for non-response items and choosing the designated subgroup, 246 respondents remained in the sample. The average age of the respondents was $25.10(S D=$ 4.74), and respondents' ages ranged from 18 to 62 years old. Of the respondents, $125(50.8 \%)$ were male, and $121(49.2 \%)$ respondents were female. With respect to marital status, 193 respondents $(78.46 \%)$ were single, while 53 respondents $(21.54 \%)$ were married. The average length of residence in Seoul was 16.41 years $(S D=9.69)$. For 101 respondents $(41.1 \%)$, the maximum educational level was a high school diploma, and 145 respondents $(58.9 \%)$ had at least a community college diploma.
We used a structural equation modeling (SEM) using LISREL 8.0 to explain the relations among media exposure, perception, and evaluation. Figure 3 presents the results of the structural model. This structural model consists of six latent variables: (1) exposure to the South Korean mass media coverage of the Ohno issue (OHNO), (2) exposure to the South Korean mass media coverage of the Boeing F-15K issue $(\mathrm{F} 15 \mathrm{~K})$, (3) perceptions of the American Olympic Team's performance in Salt Lake City (OLYM), (4) perceptions of American government (GOVN), (5) evaluation of the American soccer team's performance in the match between America and South Korea in the 2002 South Korea-Japan World Cup (WCUP), and (6) evaluation of the terrorist attack on the World Trade Center (SEPT). Before performing a structural model, a measurement model test of each latent variable was performed to see how each latent variable is measured or operationalized by corresponding manifest indicators [8].

Measurement model 1. Exposure to the South Korean mass media coverage of negative images of Americans. The concept of exposure to the South Korean mass media's coverage of negative images of Americans was comprised of two factors: exposure to the South Korean mass media coverage of the Ohno issue and the Boeing F-15K, issue respectively. To measure exposure to the South Korean mass media coverage of the Ohno issue, respondents were asked to indicate the degree of consumption of the South Korean mass media coverage on the Ohno issue per week in television at that time $(M=3.55 ; S D=.79)$, the Internet $(M$ $=3.29 ; S D=.94)$, and newspaper $(M=3.33 ; S D=.91)$ on a five-point scale (coded as Often $=5$, Sometimes $=4$, Neutral $=3$, Rarely $=2$ and Never $=1$ ). These indicators were combined to obtain a score of a respondent's exposure to the South Korean mass media coverage of the Ohno issue. A reliability test using McDonald's $\Omega$ showed an excellent reliability (.86).

Respondents' exposure to the South Korean mass media coverage of the Boeing F-15K issue was measured by asking respondents to indicate their degree of exposure to the South Korean mass media coverage of the Boeing F-15K issue per week in television at that time $(M=3.14 ; S D=.98)$, the Internet $(M=2.78 ; S D=1.13)$, and newspaper $(M=2.98$; $S D=1.03)$ on a five-point scale (coded as Often $=5$, Sometimes $=4$, Neutral $=3$, Rarely $=2$ and Never $=1$ ). These three indicators were combined to attain a score of a respondent's exposure to the South Korean mass media coverage of the Boeing F-15K issue (McDonald's $\Omega=.87$ ).

A Confirmatory Factor Analysis (CFA) was performed through LISREL 8.0 to determine how well this two-factor model measures the concept of exposure to the South Korean mass media coverage of negative images of Americans [15].The goodness-of-fit index was arranged based on Joreskog and Sorbom's three suggested categories: the $\chi^{2}$ $\operatorname{test}(8, N=246)=50.33, \mathrm{p}<.05, \mathrm{RMSEA}=.07, \mathrm{RMR}=.04$, $\mathrm{AGFI}=.90$, and GFI $=.96$ for an absolute fit measure; NFI (.95) and NNFI (.91) for an incremental fit measure; and CFI (.96), IFI (.96), and RFI (.90) for a parsimonious fit measure. 
On most goodness-of-fit indices, values of .90 and above are considered desirable, and the root-mean-squared error of approximation (RMSEA) values and Root Mean Square Residual (RMR) values of .08 or less are also considered indicators of a fairly good fit. In terms of these three fit measure categories, this model is an excellent fit due to the high values of the goodness-of-fit indices, except for the $\chi^{2}$ test. Although the $\chi^{2}$ test here is statistically significant, meaning that this model does not have a good fit, we can ignore the $\chi^{2}$ test due to our large sample size $(\mathrm{n}=246)$ since the $\chi^{2}$ test tends to be significant regardless of the degree of fitness when there is a large sample size [1]. Since the results of the Confirmatory Factor Analysis provided excellent fit-indices, these three indicators of exposure to the South Korean mass media coverage of the Ohno issue and Boeing F-15K were combined to attain a score of respondents' exposure to the South Korean mass media coverage of negative images of Americans.

Measurement model 2. Perceptions of the American Olympic Team's performance in Salt Lake City: South Koreans' perceptions of the American Olympic Team's performance refer to their general perceptions after being exposed to the South Korean mass media such as television, the Internet, and newspaper coverage of the Ohno issue. In order to evaluate this concept, respondents were asked to rate their perceptions of the American Olympic Team's performance on a seven-point semantic differential scale. Higher scores were representative of a more positive response and lower scores were representative of a more negative response. The indicators included "Unfair-Fair," $(M=2.36 ; S D=.72)$; "Arrogant-Humble" $(M=2.54 ; S D=.92)$; "Mean-Nice," $(M=2.80 ; S D=1.15) ; " U n r e s p e c t a b l e-R e s p e c t a b l e "$, $(M=2.49, S D=.88)$ "Cannot be trusted-Can be trusted," $(M=2.49 ; S D=.87)$; "Undependable-Dependable," $(M=$ $2.57 ; S D=.96)$ and "Unethical-Ethical" $(M=2.44 ; S D=.86)$. A reliability test using McDonald's $\Omega$ showed an excellent reliability (0.95).

In order to determine how well the seven indicators measure the concept of perceptions of the American Olympic Team's performance, a confirmatory factor analysis (CFA) was performed through LISREL. The outcome of this CFA indicates that this measurement model has an excellent fit, $\chi^{2}(8, N=246)=50.33, \mathrm{p}<.05$, RMSEA $=.13 ; \mathrm{RMR}=.04$, and GFI $=.94$ for an absolute fit measure; $\mathrm{NFI}=.95$ and NNFI $=.91$ for an incremental fit measure; and $\mathrm{CFI}=.96$, IFI $=.96$, and $\mathrm{RFI}=.90$ for a parsimonious fit measure. Even though the $\chi^{2}$ test is significant, we can, as mentioned before, ignore the $\chi^{2}$ test due to the large sample size. Thus, this model was accepted and the seven indicators were added together to attain a score of respondents' perceptions of the American Olympic Team's performance in Salt Lake City.

Measurement Model 3. Perceptions of American government: The perceptions are defined as general perceptions of American government from the Boeing F-15K selection procedure that was covered in the South Korean mass media that included television, the Internet, and newspapers. The perceptions of American government used in this analysis mainly consist of seven pairs of adjectives on a seven-point semantic differential scale. Respondents were asked to rate their perceptions of American government related to the Boeing F-15K issue on this scale. As before, a higher score represents a positive response, while a lower score represents a negative response. The adjectives include: "Unfair-Fair," $(M=3.03 ; S D=1.15)$; "Arrogant-Humble," $(M=3.12 ; S D=1.21)$; "Mean-Nice," $(M=3.44 ; S D=1.23)$; "Unrespectable-Respectable," $(M=3.05, S D=1.14)$ "Cannot be trusted-Can be trusted," $(M=3.06 ; S D=1.15)$; "Undependable-Dependable," $(M=3.12 ; S D=1.18)$ and "Unethical-Ethical" $(M=3.08, S D=1.19)$. A reliability test (McDonald's $\Omega=.96$ ) shows excellent reliability.

In order to determine how well these indicators measured this concept, a confirmatory factor analysis (CFA) was again performed using LISREL 8. The outcome of this CFA indicates that this measurement model has an excellent fit: $\chi^{2}$ $(14, N=246)=101.41, \mathrm{p}<.05, \mathrm{RMSEA}=.06 ; \mathrm{RMR}=.05$, $\mathrm{GFI}=.90$ and $\mathrm{AFGFI}=.90$ for an absolute fit measure; NFI $=.97$ and $\mathrm{NNFI}=.95$ for an incremental fit measure; and CFI $=.97, \mathrm{IFI}=.97$, and RFI $=.95$ for a parsimonious fit measure. Finally, this model was accepted because most goodness-of-fit indices have excellent values, and the seven indicators were added together to attain a score of respondents' perceptions of American government.

Measurement Model 4. Evaluation of the American soccer team's performance in the match between America and South Korea in the 2002 South Korea-Japan World Cup: The evaluation of the American soccer team's performance is defined as a general evaluation based on their performance in the match between America and South Korea. This concept mainly consists of five pairs of contrasting adjectives on a seven-point semantic differential scale: "Disgusted-Pleased," $(M=3.12 ; S D=1.32)$; "Frustrated-S atisfied," $(M=3.31 ; S D=1.24)$; "Angry-Happy," $(M=3.45$; $S D=1.29)$; "Worried-Hopeful," $(M=3.31 ; S D=1.17)$; and "Pessimistic-Optimistic." $(M=3.40 ; S D=1.28)$. The higher the score, the more positive the evaluation of the U.S. soccer team's performance, while the lower the score, the more negative the evaluation (McDonald's $\Omega=.93$ ).

A Confirmatory Factor Analysis (CFA) using LISREL 8.0 was performed to determine how well these indicators consistently measure the concept. The outcome of this CFA indicates that this measurement model has a fairly good fit: the $\chi^{2}$ test, $\chi^{2}(5, N=246)=18.55, \mathrm{p}<.05$, RMSEA $=.05$; $\mathrm{RMR}=.03, \mathrm{AGFI}=.91$, and GFI $=.97$ for an absolute fit measure; NFI $=.99$ and NNFI $=.98$ for an incremental fit measure; and CFI $=.99$, IFI $=.99$, and RFI $=.97$ for a parsimonious fit measure. Since the result of the Confirmatory Factor Analysis provided excellent fit-indices, the suggested five indicators were added together to obtain a score of respondents' evaluations of the American soccer team's performance in the match between America and South Korea in the 2002 South Korea-Japan World Cup. Finally, the data from these five indicators was combined to attain a single concept: South Koreans' evaluation of the U.S. 
soccer team's performance in the match between America and South Korea in the World Cup.

Measurement Model 5. Evaluation of the terrorist attack on the World Trade Center: Evaluation of the terrorist attack on the World Trade Center is defined as South Koreans' evaluation measured during the period of flourishing anti-Americanism in South Korea. This concept was measured by asking respondents to rate their evaluation of the terrorist attack on the World Trade Center on five pairs of adjectives on a seven-point semantic differential scale: "Disgusted-Pleased," $(M=3.74 ; S D=1.63)$; "Frustrated-S atisfied,"(3.65; $S D=1.55)$; "Angry-Happy," $(M=3.52 ; S D$ $=1.53)$; "Worried-Hopeful," $(M=3.00 ; S D=1.54)$; and "Pessimistic-Optimistic." $(M=3.30 ; S D=1.50)$. A reliability test (McDonald's $\Omega=.96$ ) shows an excellent reliability.

A Confirmatory Factor Analysis (CFA) was performed and the outcome indicated that this measurement model has a fairly good fit except for the $\chi^{2}$ test: $\chi^{2}(5, N=246)=35.24, \mathrm{p}$ $<.05$, RMSEA $=.13$; RMR $=.05$, and GFI $=.94$ for an absolute fit measure; NFI $=.98$ and NNFI $=.95$ for an incremental fit measure; and CFI $=.98, \mathrm{IFI}=.98$, and RFI $=.95$ for a parsimonious fit measure. Because the results of the Confirmatory Factor Analysis provided excellent fit-indices, these five indicators were combined together to attain a score of respondents' evaluation of the terrorist attack on the World Trade Center.

Structural Model. Given the five measurement models depicting the links between the latent variables and their observed measures, we tested an initial structural model depicting the links among the six latent variables themselves using the LISREL program. Figure 3 presents the results of the structural model.

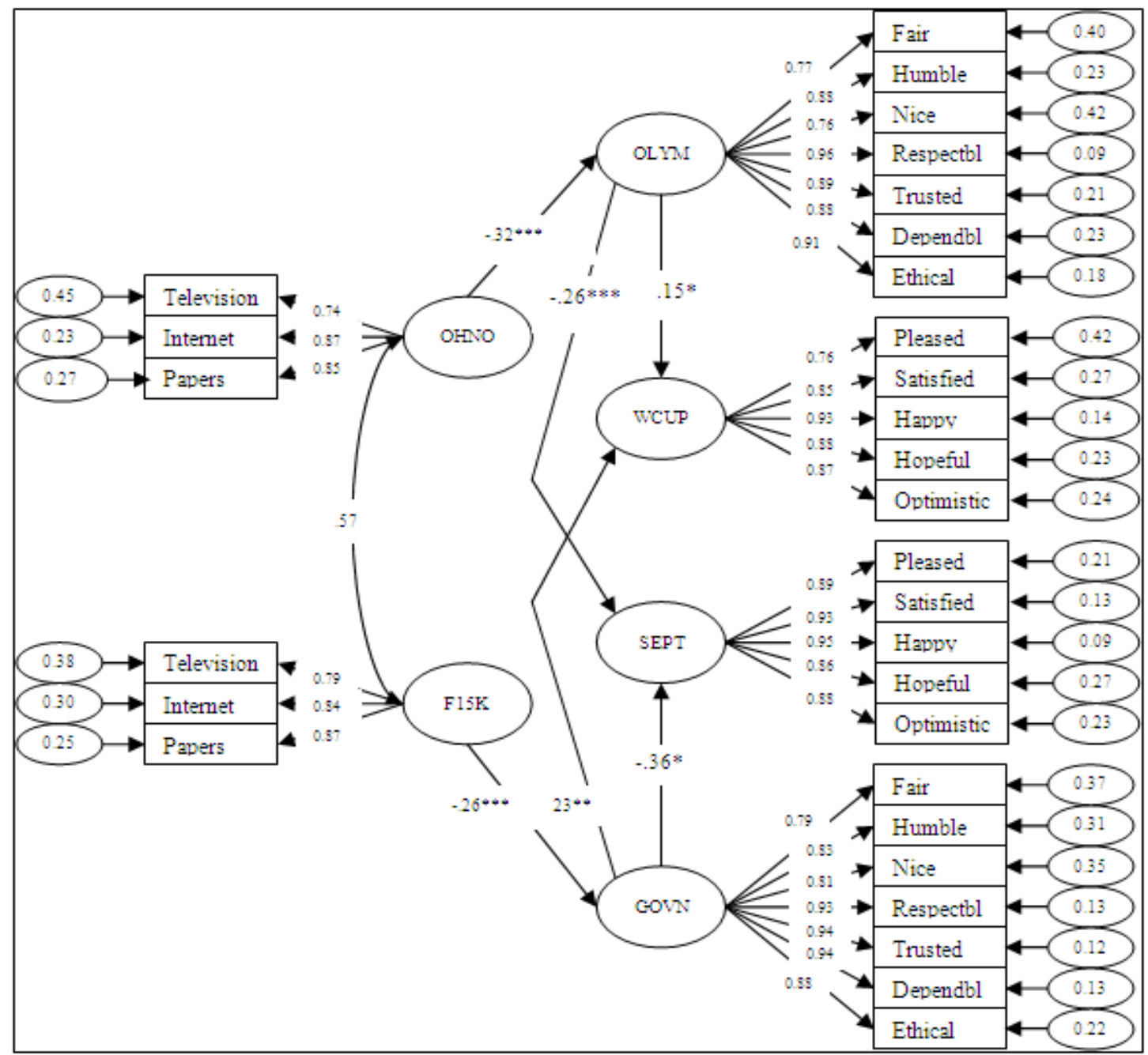

Figure 3. Structural equation modeling; parameter estimates are standardized by ML. $\underline{\mathrm{OHNO}}=$ exposure to the South Korean mass media coverage of the Ohno issue; F15K =exposure to the South Korean mass media coverage of the Boeing F-15K issue; OLYM = perceptions of the American Olympic Team's performance in Salt Lake City; GOVN = perceptions of American government; $\underline{\text { WCUP }}=$ evaluation of the American soccer team's performance in the match between America and South Korea in the 2002 South Korea-Japan World Cup; SEPT $=$ evaluation of the terrorist attack on the World Trade Center. (significance levels are determined by critical ratios, ${ }^{*}: \mathrm{p}<.05, * *: \mathrm{p}<.01, * * *: \mathrm{p}<.001$.) 
First, in order to test the extent to which this structural model is consistent with the data, the goodness-of-fit index was tested, based on the three suggested categories we used in the measurement models: the $\chi^{2}$ test $(394, N=246)=5572$, $\mathrm{p}<.05$, RMSEA (.06), RMR (.05), AGFI (.93), and GFI (.91) for an absolute fit measure; NFI (.92) and NNFI (.92) for an incremental fit measure; and CFI (.93), IFI (.93), and RFI (.91) for a parsimonious fit measure. In terms of these three fit measure categories, this model has an excellent fit due to the high values of the goodness-of-fit indices. Additionally, our assessment of the overall model was also confirmed by the Q-plot of standardized residuals that is characterized by points falling approximately on a $45^{\circ}$ line in the LISREL output [5].

Effects decomposition. Structural Equation modeling (SEM) is one of the best methods for analyzing direct, indirect, and total effects among latent variables. However, the direct and indirect effects in this structural model are also total effects themselves since the six suggested latent variables do not have more than one indirect effect on each other (See Table 1).

Direct Effects. In the terminology of this structural model, each $\beta$ and $\gamma$ in the diagram represents a direct effect. The direct effect of one variable on another is not mediated by another variable [17]. For example, the first exogenous variable, exposure to the South Korean mass media coverage of the Ohno issue was statistically related to South Koreans' negative perceptions of the American Olympic Team's performance, supporting $\mathrm{H} 1$ (standardized $\gamma_{1}=-.32$, $\mathrm{p}<.001)$. Another exogenous variable, exposure to the South Korean mass media coverage of the Boeing F-15K issue, was also statistically related to South Koreans' negative perceptions of American government, supporting $\mathrm{H} 2$ (standardized $\gamma_{41}=-.26, \mathrm{p}<.001$ ).

As expected, the regression coefficient relating the perceptions of the American Olympic Team's performance in Salt Lake City, contained in the $\beta$ matrix, was positively related to the evaluation of the American soccer team's performance in the World Cup, supporting $\mathrm{H} 3\left(\beta_{21}=.15\right.$, $\mathrm{p}<.05$ ). Also, the perceptions of American government had a positive relationship to the evaluation of the American soccer team's performance in the World Cup. In particular, the standardized coefficient of $.23\left(\beta_{24}\right)$ represents a medium positive effect, supporting $\mathrm{H} 4(\mathrm{p}<.01)$.

Similarly, perceptions of the American Olympic Team's performance in Salt Lake City were positively related to the negative evaluation of the terrorist attack on the World Trade Center. The value $-.26\left(\begin{array}{ll}\beta_{3} & 1\end{array}\right)$ in the $\beta$ matrix is the standardized coefficient of the direct effects of South Koreans' perceptions of the American Olympic Team's performance on the negative evaluation of the terrorist attack on the World Trade Center, supporting H5 ( $\mathrm{p}<.001)$. Also, the perceptions of American government had a significant effect on the negative evaluation of the terrorist attack on the World Trade Center in 2001, supporting H $6\left(\beta_{34}=-.36\right.$, p $<.05)$.

Table 1. Decomposition of Standardized Effects for Media Effects on Anti-Americanism

\begin{tabular}{|c|c|c|c|c|}
\hline \multirow[b]{2}{*}{ Causal Variable } & \multicolumn{4}{|c|}{ Endogenous Variable } \\
\hline & $\underline{\text { OLYM }}$ & WCUP & $\underline{\text { SEPT }}$ & $\underline{\text { GOVN }}$ \\
\hline \multicolumn{5}{|l|}{$\underline{\mathrm{OHNO}}$} \\
\hline Direct effect & $-.32 * * *$ & - & - & - \\
\hline Indirect via OLYM & - & $-.04 *$ & $.08 * * *$ & - \\
\hline \multicolumn{5}{|l|}{$\underline{\mathrm{F} 15 \mathrm{~K}}$} \\
\hline Direct effect & - & - & - & $-.26^{* * *}$ \\
\hline Indirect via GOVN & - & $-.06 * * *$ & $.09 * *$ & - \\
\hline \multicolumn{5}{|l|}{$\underline{\text { OLYM }}$} \\
\hline Direct effect & - & $.15^{*}$ & $-.26 * * *$ & - \\
\hline Indirect effect & - & - & - & - \\
\hline \multicolumn{5}{|l|}{$\underline{\text { GOVN }}$} \\
\hline Direct effect & - & $.23 * *$ & $-.36^{*}$ & - \\
\hline Indirect effect & - & - & - & - \\
\hline
\end{tabular}

$*: \mathrm{p}<.05, * *: \mathrm{p}<.01, * * *: \mathrm{p}<.001 ;$ All entries are final standardized coefficients $(\mathrm{n}=246)$.

Standardized path coefficients with absolute values less than .10 may indicate a "small" effect; values around .30, a "medium" effect; and those greater than .50, a "large" effect (Kline, 1998, p.118). OHNO =exposure to the South Korean mass media coverage of the Ohno issue; $\underline{F} 15 \mathrm{~K}=$ exposure to the South Korean mass media coverage of the Boeing F-15K issue; OLYM = perceptions of the American Olympic Team's performance in Salt Lake City; GOVN = perceptions of American government; WCUP = evaluation of the American soccer team's performance in the match between America and South Korea in the 2002 South Korea-Japan World Cup; SEPT $=$ evaluation of the terrorist attack on the World Trade Center. (significance levels are determined by critical ratios, *: $\mathrm{p}<.05, * *: \mathrm{p}<.01, * * *: \mathrm{p}<.001$.) 
Indirect Effects. Indirect effects involve one or more intervening variable (or mediator variables) that "transmit" some of the causal effects of prior variables onto subsequent variables. For example, we can test the indirect effects of how exposure to the South Korean mass media coverage of both the Ohno and the Boeing F-15K issues are indirectly related to South Koreans' respective evaluations of both the American soccer team's performance in the American and South Korean match of the South Korea-Japan World Cup, and the terrorist attack on the World Trade Center. In this study, latent variables of both the perceptions of the American Olympic Team's performance in Salt Lake City, and perceptions of American government are mediator variables. Since it is expected that people tend to acquire negative or positive perceptions of an issue after being exposed to media coverage, these perceptions probably affect people's positive or negative evaluation toward future events. Thus, the exposure to the South Korean mass media coverage of the Ohno issue was indirectly related (through perceptions of the American Olympic Team's performance in Salt Lake City) to South Koreans' negative perceptions of the American World Cup Team's performance $\left(\gamma_{11^{*}} \beta_{21}=\right.$ $-.04, \mathrm{p}<.05$ ), supporting H7. Thus, South Koreans' positive evaluation of the terrorist attack on the World Trade Center $\left(\gamma_{1} 1_{1} \beta_{31}=.08, p<.001\right)$ supports H8. Finally, it is noteworthy that exposure to the South Korean mass media coverage of the Boeing F-15K issue was indirectly related to negative evaluation of the American soccer team's performance in the 2002 South Korea-Japan World Cup, supporting $H 9\left(\gamma_{42} * \beta_{24}=-.06, p<.001\right)$, while the positive evaluation of the terrorist attack on the World Trade Center $\left(\gamma_{42 *} \beta_{34}=.09, p<.01\right)$ supports H10.

\section{Discussion}

Today, anti-Americanism exists in many countries such as Germany, Lebanon, Greece, Turkey, and other European countries [13]. Anti-Americanism also exists in South Korea, and it is surmised that two issues, the Olympic short track speed skating controversy and the U.S. Boeing F-15K issue, might affect the origin of the anti-Americanism of South Koreans in South Korea. Thus, we tested how these issues affected South Koreans' recent changes in feelings and attitudes about well-known American-coded issues like the American soccer team's performance in the 2002 South Korea-Japan World Cup, and the terrorist attack on the World Trade Center in 2001.

First, the findings in this research using structural equation modeling indicate that exposure to the South Korean mass media coverage of two well-known negative exemplars, the Ohno controversy and the Boeing F-15K issue, was positively related to respondents' negative perceptions of the American Olympic Team's performance in Salt Lake City, as well as negative perceptions of American government, respectively. Also, since South Koreans' perceptions of the American Olympic Team's performance in Salt Lake City were positively related to their negative evaluation of the terrorist attack on the World Trade Center in 2001, and positive evaluation of the American soccer team's performance in the 2002 South Korea-Japan World Cup, respectively, the media exposure to the Ohno issue, in addition to being indirectly related to South Koreans' positive evaluation of the terrorist attack on the World Trade Center, was indirectly related (through perceptions of the American Olympic Team's performance in Salt Lake City) to respondents' negative evaluation of the American soccer team's performance in the World Cup. Similarly, it was also revealed that South Koreans' perceptions of American government were positively related to their evaluation of the American soccer team's performance in the 2002 South Korea-Japan World Cup, as well as to their negative evaluation of the terrorist attack on the World Trade Center in 2001. Therefore, in terms of indirect effects, the media exposure to the Boeing F-15K issue was indirectly related (through perceptions of American government) to South Koreans' negative evaluation of the U.S. World Cup team's performance, and positive evaluation of the terrorist attack on the World Trade Center.

Second, the results of this study support previous studies arguing that individuals rely on media coverage of a group to create their perceptions when they lack real-world experience with that group. Therefore, it can be concluded that exposure to the South Korean mass media with a negative bias toward Americans is one of the factors facilitating anti-Americanism in South Korea among most South Koreans who do not have direct contact with Americans. Since we theoretically have revealed that the exposure to the South Korean mass media coverage of American images was statistically related (through perceptions toward Americans) to the evaluation of American-coded issues, we conclude that exposure to the mass media coverage of negative exemplars of America is one of the potential factors causing anti-Americanism in South Korea. This supports the previous pro-American groups' opinion that the South Korean mass media, by covering negative American exemplars, has facilitated anti-Americanism in South Korea, and is responsible for negative relations between the two countries [14].

Third, these findings support exemplification theory and social cognitive theory in that a series of negatively weighted exemplars (i.e., the Ohno issue and the F-15K issue) fostered negative evaluation of American-coded issues. For example, the outcome of the America vs. South Korea soccer match was a tie, and the South Korean team's number of fouls (5 yellow cards) was higher than that of the American team (4 yellow cards). Despite the fact that the South Korean teams' performance was poorer than the American team's performance, South Koreans evaluated the American team's performance more negatively because the audience was already schematized by previous negative exemplars (called exemplar information). This disregard of statistical or empirical data such as the number of yellow cards or scientific principles (called base-rate information), is 
expected by Zillmann and Brosius in their exemplification theory. Also, the process by which South Koreans formed perceptions and evaluation about American-coded issues can be explained through the four major subfunctions of media that Bandura posits to explain the process of human knowledge formation in his social cognitive theory. Bandura's conclusion that program contents of mass media were as effective as real life models on influencing human perception, behavior, and belief is evident in the pro- or anti-American schema created by South Koreans in this survey, since the South Korean mass media exposure shapes South Koreans' perceptions of Americans.

This study focused primarily on how domestic media coverage of negative exemplars of America facilitates South Koreans' perceptions of Americans, ultimately leading to anti-Americanism. Based on this outcome, it would be interesting to study other countries' pro- or anti-Americanism. Thus, further studies should include a replication of this study in other countries, especially countries with both positive and negative perceptions of America. It would be interesting to compare how media in each country cover America, and how such coverage influences the perceptions of the citizens. Since the media of each country may cover America differently, depending on how coverage supports the government of that country, it is predicted that audience perceptions of America in each country will be different.

\section{Notes}

1. Cited from the annual report of South Korea Tourist Service. http://www.knto.or.kr/PATA/

2. Survey in South Korea Joongang Journal in South Korea, March, 2, 2002; public opinion poll period: 2/27/2002-3/1/2002.

3. Survey in Khan Journal in South Korea, March, 6, 2002; public opinion poll period: 2/26/2002-3/05/2002 .

4. Survey in Khan Journal in South Korea, March, 14, 2002; public opinion poll period: 3/07/2002-3/14/2002.

5. Survey in Khan Journal in South Korea, September, 18, 2002; public opinion poll period: 12/02/2001-12/09/2001.

6. Survey in Khan Journal in South Korea, September, 18, 2002; public opinion poll period: 9/26/2001-10/03/2001.

\section{REFERENCES}

[1] Bagozzi, R. P., \& Yi, Y. (1988). On the evaluation of structural equation model. Journal of the Academy of Marketing Sciences. 16, 74-94.

[2] Bandoim, L.(2013). Apolo Ohno retirement: Ohno retires from competition. In examiner.com. Retrieved April, 27,2013, from http://www.examiner.com/article/apolo-ohnoretirement-ohno-retires-from-competition.
[3] Bandura, A. (2002). Social cognitive theory of mass communication. In J. Bryant \& D. Zillmann ( $2^{\text {nd }}$ ed.), Media Effects: Advances in theory and research (pp. 121-153). Hillsdale, NJ: Lawrence Erlbaum.

[4] Bathory, P. D. \& McWilliams, W.C. (1977). Political theory and the people's right to know. In I. Galnoor (Ed.), Government secrecy in democracy, (pp. 3-21). New York, NY: Praeger.

[5] Browen, M. W. \& Cudeck, R. (1993). Alternative ways of assessing model fit in testing structural equation model. Thousand Oaks, CA: Sage.

[6] Chang, T. K. (1993). The press and China policy: the illusion of Sino-American relations, 1950-1984. New Jersey: Ablex.

[7] Chung, H. (2001, September 18). Justice in retribution. South Korea Herald, Seoul, South Korea.

[8] Diamantopoulos, A., \& Siguaw, J. (2000). Introducing LISREL. Newbury Park, CA: Sage.

[9] Fujioka, Y. (1999). Television coverage and African-American stereotypes: Examination of television effects when direct contact is lacking. Journalism and Mass Communication Quarterly. 76(1), 52-75.

[10] Gilens, M. (1996). Race coding and white opposition to welfare. American Political Science Review. 90, 593-604.

[11] Herman, E. S. and Chomsky, N. (1988) Manufacturing consent: The political economy of the mass media. New York, NY: Pantheon Books.

[12] Hwang, J. (2002, April 24). F-X winner Boeing to provide South Korea with unmanned aircraft technology, South Korea Herald, Seoul, South Korea

[13] Immerfall, S.(2011). Perennial Anti-Americanism in Germany? Critical comments on Ruth Hatlapa's and Andrei S. Markovits' 'Obamamania and Anti-Americanism as Complementary Concepts'. German Politics \& Society. 29(4), 78-81.

[14] Jang, C. (2003, April 9). Misinterpretation facilitating Anti-Americanism. Chosun Times. Seoul, South Korea.

[15] Joreskog, K., \& Sorbom, D. (1996). LISREL 8: User's reference guide. Chicago, IL: Scientific Software International.

[16] Josslin, B. (2001, September 13). American expatriates in South Korea united in shock. South Korea Herald. Seoul, South Korea.

[17] Kaplan, D. (2000). Structural Equation Modeling: Foundations and Extensions. Thousand Oaks, CA: Sage.

[18] Kim, J. (2002, June 10). FIFA to take special security measures for South Korea-U.S. game. South Korea Herald. Seoul, South Korea.

[19] Kim, M. (2001, September 13). South Koreans shocked, angry over terrorist attacks in America. South Korea Herald. Seoul, South Korea.

[20] Labelle, M. M. (2013). A New Age of Empire? Arab 'Anti-Americanism', US Intervention, and the Lebanese Civil War of 1958. International History Review. 35(1),42-69. 
[21] Lee, J. (2002, June 10). Security tightened, traffic controlled in Seoul for South Korea-U.S. soccer match. South Korea Herald. Seoul, South Korea.

[22] Lialiouti, Z. (2011). Greek anti-Americanism and the war in Kosovo. National Identities. 13(2), 127-156.

[23] Lippmann, W. (1949). Public Opinion. New York: The Free Press.

[24] Qin, P. (2011). The role of anti-Americanism in the contemporary European identity building. Review of European Studies. 3(1), 94-100.

[25] Shin, Y. (2001, September 18). Kim pledges full support for U.S. reprisal strike. South Korea Herald. Seoul, South Korea.

[26] Soh, J. (2002a, April 5). Citizens urge boycott of U.S. products.
South Koreatimes. Seoul, South Korea.

[27] Soh, J. (2002b, March 27). Civic Groups Oppose Selection of F-15K for Fighter Project. South Koreatimes, Seoul, South Korea.

[28] Turkmen, F. (2010). Anti-Americanism as a Default Ideology of Opposition: Turkey as a Case Study. Turkish Studies. 11(3), 329-345.

[29] Zillmann, D. (2002). Exemplification theory of media influence. In J. Bryant \& D. Zillmann ( $2^{\text {nd }}$ ed. $)$, Media Effects: Advances in theory and research (pp. 19-41). Hillsdale, NJ: Lawrence Erlbaum. Zillmann, D. \& Brosius, H. (2000). Exemplification in Communication: The influence of case reports on the perceptions of issues. Mahwah, New Jersey: Lawrence Erlbaum. 